\title{
GOVERNING FROM THE MARGINS: THE EUROPEAN COURT OF HUMAN RIGHTS' MARGIN OF APPRECIATION DOCTRINE AS A TOOL OF GLOBAL GOVERNANCE
}

\author{
Simon Paul*
}

\begin{abstract}
Summary: The European Court of Human Rights' margin of appreciation doctrine is of growing importance in general international law. Existing scholarship, however, fails to consider the political stakes involved in its use. The aim of this paper is to offer a reconceptualisation of the margin as a tool of global governance in the context of the increasing judicialisation of human rights protection in Europe. It then proposes four sketches of its possible governance effects, situating it within broader debates concerning competing models of international constitutionalisation, the Court's unarticulated discrimination between different European States, and the challenges the Court faces in maximising compliance with its judgments. The paper concludes by arguing that the Court's use of the margin as an 'escape valve' to avoid potentially controversial proportionality assessments poses a challenge to its long-term legitimacy, and involves a kind of 'bad faith' exercise of its governance power.
\end{abstract}

\section{Introduction}

On the website of the Council of Europe can be found a mysterious document entitled 'The Margin of Appreciation'. ' Over several pages, the document provides an outline of a legal doctrine used by the European Court of Human Rights, with sections entitled 'Interpretive Principles', 'The Margin of Appreciation Doctrine in the Jurisprudence of the European Court of Human Rights', and a final section providing 'Conclusions'. The mystery arises from the apparent absence of an author: one has to peer very closely at the end of the text, after the bibliography, to discover that it is credited to the 'Romanian team of the National Institute of Magistracy'. This reduction of the author's presence is all the more striking when one casts a critical eye over the contents of the document. It references many of the leading scholarly works concerning the margin

\footnotetext{
* Barrister, Fountain Court Chambers, London. This paper is based on the author's LLM thesis at Harvard Law School. The author is indebted to Professor David Kennedy and Dr Michail Dekastros for their invaluable comments and suggestions.

1 Council of Europe, 'The Margin of Appreciation' <www.coe.int/t/dghl/cooperation/lisbonnetwork/themis/echr/paper2_en.asp> accessed 2 December 2016.
} 
of appreciation, a body of scholarship rich in disagreement. Yet the tone of the document itself is clear: as the margin of appreciation is an 'inherent and permanent phenomenon under the Convention' there must exist 'principled criteria' for its application, and the purpose of the study is to 'identify and explain them'. ${ }^{2}$

Are we to take this as a statement of the settled view of the European Court of Human Rights as to the margin of appreciation, perhaps as an expression of its self-image? Its presence on the Council of Europe website, and the authorless quality of it, suggests we might. Yet a closer look reveals that, if this is a self-image, then it is a confused one. For in the same paragraph that the document asserts the 'inherent and permanent' nature of the margin of appreciation, there also sits another claim. That the "process of realizing a "uniform standard" of human rights protection must be gradual because the entire legal framework rests on the fragile foundations of the Member States' (emphasis added). Thus, in a single paragraph, we have an unfolding process, an identifiable mission, alongside an 'inherent and permanent phenomenon' that seems at odds with that goal. The juxtaposition of these two statements suggests a nightmarish image: of an institution with a clear destination, which it is condemned never to reach, like a boat propelled by oarsmen rowing in opposite directions.

But perhaps the document is not supposed to represent the views of the Court at all. It is, after all, found on the website of the Council of Europe, a body composed of the states who appear as litigants in the Court, and whose victories routinely depend on the margin of appreciation. Yet this understanding might lead us to treat with suspicion its claims of 'permanence' and 'inherency', and also the search for 'principled criteria'. For, as the document itself concedes (again, in the same paragraph), the margin of appreciation gives the Court the 'flexibility' to avoid 'damaging confrontations' between it and the Member States. A sceptical reader might question whether this doctrine avoids damaging confrontations, or merely settles them in favour of the State. We might also question whether the search for a principled basis is fundamentally at odds with the demand for flexibility, and whether the claims made in the document are as uncontroversial as its authorless quality suggests, or in fact represent the victory of one oarsman in this never-ending struggle.

The purpose of this paper is to consider the margin of appreciation in light of this institutional conflict. It will be suggested that the margin of appreciation can be seen as a symptom of the governance dilemma that arises from two different sets of commitments inherent in the European Court of Human Rights: its foundation in a treaty-based system,

2 ibid. 
reflecting public international law's regard for sovereign States, and the transnational universalism of human rights. The aim will be to suggest that whilst the margin of appreciation is not 'inherent', this conflict is. The margin itself as a solution to that conflict is contingent, yet over time it has acquired the aura of necessity. This paper seeks to diminish, or at least question, that aura, by considering the governance effects of the margin of appreciation.

The paper proceeds as follows. In the first section, a brief introduction to the doctrine will be offered, followed by an assessment of the current state of scholarship. This suggests that there is a lacuna in the scholarly work: whilst many theorists seek to defend or critique the margin of appreciation, there has been no attempt to assess its governance effects. Then some of the key justifications for the doctrine, and attempts to found it on a 'principled basis', will be considered. It will be argued that the common justifications fail to provide such a principled basis, and as such a reconceptualisation of the doctrine as a 'tool' will be suggested. This leads to the further question: what, or whom, is it a tool for? What are the political stakes involved in the use of the margin of appreciation? Who wins, and who loses, by the existence of this judicial tool?

The remainder of the paper attempts to answer this, by offering four sketches of the effects of the margin of appreciation reconceptualised as a governance tool. None of these are supposed to be conclusive, but all, it is hoped, will suggest ways of thinking about the margin of appreciation that might lead to a different assessment of it. The first sketch argues that the margin of appreciation can be seen as taking a stake in the clash between two different visions of international constitutionalisation: the post-statist model, and the traditional nation-state trajectory. It will be argued that the margin of appreciation reverts constitutionalising capacity back to the nation-state, aiding in the capture of the processes of constitutionalisation by public institutions using human rights norms. The second sketch views the margin of appreciation as an aspect of the Court's unarticulated discrimination between Member States, arguing that its inconsistent use vis-à-vis different States reflects the tension between the teleology of human rights and the regard for the sovereignty of its members arising from the treaty-based system. The third sketch situates the margin of appreciation in the context of the Court's challenge of ensuring compliance with its judgments. It suggests that the margin of appreciation, somewhat counter-intuitively, is used by the Court as a way of avoiding issuing costly judgments against States, so as to build up compliance respect that it can later cash in, aiding the steady expansion of its governance power.

The final section considers the relationship between the margin of appreciation, proportionality and balancing of rights. It argues that the 
margin of appreciation enables the Court to give the impression of avoiding taking a stake in issues of conflict and distribution. Yet, the analysis suggests, this is a false impression, as when the Court deploys the margin it cannot help taking such a stake. It is then argued that this suggests a problem for the Court's legitimacy and effectiveness, and that a better approach might be for the Court to rely more on its own assessments of proportionality and balancing of interests. An understanding of the political stakes involved in such a development would require a more complete theory of the 'politics of separation of powers', considered in the context of an inter-governmental human rights court. Various avenues for future research are suggested.

The paper finishes by concluding that, although the margin of appreciation is here to stay, it is by no means 'inherent' or 'permanent', but is the result of specific doctrinal choices, which represent the victory of one aspect of the Court's identity over another. Although the two oarsmen of universalist human rights and statism are in a constant struggle, the paper seeks to show that the margin of appreciation cannot provide a solution to that problem. It is a symptom of it, and to pretend that it is necessary is to mask the political stakes that accompany the use of such a tool, and disguise alternative paths for European governance that might handle those stakes differently.

\section{The margin of appreciation: flexible tool or principled basis?}

\subsection{Origins and current scholarship}

The margin of appreciation refers to the latitude the European Court of Human Rights sometimes gives to national authorities, whether legislative, administrative or judicial, in implementing the human rights guarantees under the European Convention. It first appeared in the Court's judgments in the context of article 15, which enables States to derogate from their duties under the Convention in times of 'war, or other public emergency threatening the life of the nation'. ${ }^{3}$ The State was granted a 'certain margin of appreciation' in determining whether such circumstances had arisen. ${ }^{4}$ The genealogy of the doctrine can be traced through martial law, and the jurisprudence of the French Conseil d'État, and other continental administrative review bodies. ${ }^{5}$ In a series of judgments, beginning with Handyside $v$ United Kingdom in 1976, the Court extended

\footnotetext{
3 Convention for the Protection of Human Rights and Fundamental Freedoms, art 15 (adopted 4 November 1950, entered into force 3 September 1953) UNTS 221.

4 Greece $v$ United Kingdom App no 176/56 (European Commission of Human Rights, 1958) para 136.

5 Howard C Yourow, The Margin of Appreciation Doctrine in the Dynamics of European Human Rights Jurisprudence (Martinus Nijhoff Publishers 1996).
} 
the use of the doctrine to the 'personal freedoms' of articles 8-11. ${ }^{6}$ It has since become a central feature of the Court's jurisprudence, and potentially applicable to any claim.

The concept is also gaining traction beyond the European Court of Human Rights. It has been suggested that it should be adopted by ICSID Tribunals as an all-purpose standard of review in investor-state claims ${ }^{7}$ and as a general principle of international law that should be recognised by the ICJ. ${ }^{8}$ It has also found its way into the jurisprudence of other international human rights mechanisms, where the United Nations Human Rights Committee has employed it implicitly, and the Inter-American Court of Human Rights expressly referred to the judgments of the European Court in using it. ${ }^{9}$ At the same time, the concept has started to appear in the judgments of the Court of the Justice of the European Union, albeit in limited circumstances (and it is often referred to as an 'area of discretion' instead). ${ }^{10}$

The margin of appreciation thus has significance beyond the peculiarities of the European Convention system. However, since its inception it has been one of the most controversial aspects of the Court's jurisprudence, and has generated much scholarship. ${ }^{11}$ One recent monograph seeks to defend the margin as a judicial doctrine, by building on some of the justifications hinted at in the judgments, and using insights from the philosophy of practical reason to argue that it is a 'second-order reason' that the Court can take into account when deciding cases. ${ }^{12}$ Likewise, other contemporary theorists seek to cast the doctrine in its best light, by distinguishing between the different ways it is used by the Court, and offering normative arguments to support these different uses. ${ }^{13}$ At the same

$6 \quad$ Handyside $v$ United Kingdom (1979-80) 1 EHRR 737, paras 47-49.

7 William W Burke-White and Andreas von Staden, 'Private Litigation in a Public Sphere' (2010) 35 Yale J Intl L 283.

8 Yuval Shany, 'Toward a General Margin of Appreciation Doctrine in International Law?' (2005) 16 European J Intl L 907.

9 Ondir Bakircioglu, 'The Application of the Margin of Appreciation Doctrine in Freedom of Expression and Public Morality Cases' (2007) 8 German L J 711, 713.

10 James A Sweeney, 'A "Margin of Appreciation" in the Internal Market: Lessons from the European Court of Human Rights' (2007) 34 Legal Issues of Economic Integration, 27, 33.

11 The canonical works are Yourow (n 5), and Yutaka Arai-Takahashi, The Margin of Appreciation Doctrine and the Principal of Proportionality in the Jurisprudence of the ECHR (Intersentia 2002).

12 Andrew Legg, The Margin of Appreciation in International Human Rights Law (OUP 2012). Legg argues that the margin of appreciation is a judicial practice of assigning weight to a respondent State's reasoning in a case based on three factors: democratic legitimacy, common practice of states, and expertise.

13 See George Letsas, 'Two Concepts of the Margin of Appreciation' (2006) 26 Oxford Journal of Legal Studies 705, 706, for an attempt to distinguish between two ways the Court uses the margin: a 'substantive' use, whereby it is used to address the relationship between individual freedom and collective goals, and a 'structural' use, where the margin of ap- 
time, critique has tended to centre on the abstract theoretical inconsistency between the universalism of human rights and the accommodation of national differences, or the challenge to the rule of law posed by the ad hoc use of the doctrine. ${ }^{14}$

This paper differs, in that it seeks to move the debate away from a purely doctrinal or theoretical critique, by viewing the margin of appreciation as the expression of a governance dilemma, arising from the challenge of judicialising the project of international human rights via a treaty-based system. As such, it is presumed that the margin of appreciation not only has specific governance effects that are worth studying in their own right, but that its close relationship to the fundamental institutional conflict at the heart of the European Court makes it a useful prism through which to assess the Court's activities as a whole. This paper, then, seeks to contribute to three broad areas of literature. First, work in global governance seeking to position institutions such as the European Court of Human Rights within the discourse. ${ }^{15}$ Second, specific doctrinal debates concerning the status of the margin of appreciation in the jurisprudence of the European Court of Human Rights. ${ }^{16}$ Third, work in the new field of critical approaches to human rights, which seeks to treat human rights as an intellectual and practical project of governance that can and ought to be critiqued in politically contestable terms. ${ }^{17}$

preciation involves addressing the limits or intensity of review of the Court arising from its basis as an international tribunal.

14 See, for example, CS Feingold, 'The Doctrine of Margin of Appreciation and the European Convention on Human Rights' (1977) 53 Notre Dame Law 90; Rosalyn Higgins, 'Derogations under Human Rights Treaties' (1978) 48 British Yearbook of International Law 281, 296315; Anthony Lester, 'Universality versus Subsidiarity: A Reply' (1998) 1 European Human Rights Law Review 73; Eyal Benvenisti, 'Margin of Appreciation, Consensus and Universal Standards' (1998) 31 New York University Journal of International Law and Politics 843; and Douglas Lee Donoho, 'Autonomy, Self-Governance and the Margin of Appreciation' (2001) 15 Emory Intl L Rev 391. Jeffrey A Brauch, 'The Margin of Appreciation and the Jurisprudence of the European Court of Human Rights: A Threat to the Rule of Law' (2005) 11 Columbia J Intl L 113, argues that the lack of clear principles governing the use of the margin pose a threat to the rule of law. It is worth noting that wholesale calls for the removal of the doctrine have receded in the critical literature, and instead attempts to reconstruct and defend dominate.

15 See David Kennedy, 'The Mystery of Global Governance' (2008) 34 Ohio Northern University L Rev 827; and Jeffrey L Dunoff and Joel P Trachtman (eds), Ruling The World: International Constitutionalism And Global Governance (CUP 2009). It is, of course, an open question whether the Court can be regarded as an institution of global governance as such; see, for example, James W Nickel, 'Is Today's International Human Rights System a Global Governance Regime?' (2002) 6 The Journal of Ethics 353, for the argument that it is not. However, for the purposes of this paper it matters little whether the label of global governance is correctly applied. What matters is, as will hopefully be shown, that doctrines such as the margin of appreciation have transnational governance effects, at the very least in the European constitutional space.

16 See nn 9-11.

17 This field can be traced to an article by David Kennedy, "The International Human Rights 
That said, before moving to consider the governance effects of the margin of appreciation, it is important to understand why its characterisation as a 'tool' rather than a doctrine per se is apt. ${ }^{18}$ Of course, to a large extent the difference between legal doctrines and tools is rhetorical. All doctrines contain gaps and ambiguities that are susceptible to critical attack, and some of the most enduring judicial tropes (say, 'reasonableness' standards) sit far along the spectrum of vagueness. Yet the rhetorical difference is an important one. 'Doctrine' suggests that the particular legal device in question has a coherence and completeness that justifies its enduring presence in judgments. It suggests that practitioners will be able to orient themselves around it, that its use is neither arbitrary nor unpredictable, and that the reasons given for deploying the doctrine are those that really motivated its use. ${ }^{19}$ 'Tool', on the other hand, suggests that the legal device is being used to fulfil some function in addition to the reasons given for it in the text of the judgment. ${ }^{20}$ It invites a sceptical

\footnotetext{
Movement: Part of the Problem?' (2002) 15 Harvard Human Rights Journal 101. See R Dickinson and others (eds) Examining Critical Perspectives on Human Rights (CUP 2014) for an updated article by Kennedy with responses, and in particular, Stephen Wheatley, "The Construction of the Constitutional Essentials of Democratic Politics by the European Court of Human Rights following Sejdic and Finci' (ibid) for the argument that the European Court of Human Rights exercises a strong governance function when it elaborates the scope and content of ECHR obligations (Wheatley's striking example is the case of Sejdic and Finci where the Court held that a provision of Bosnia and Herzegovina's constitution was incompatible with art 14 of the Convention). In JM Beneto and D Kennedy (eds), New Approaches to International Law (TMC Asser Press 2013), Frédéric Mégret offers an overview of the current status of the critique of international human rights, in his contribution, 'Where Does the Critique of International Human Rights Stand? An Exploration in 18 Vignettes' (ibid, 3).

18 However, even defenders of the margin suggest this distinction is important. For example, Legg (n 12) 13, devotes part of his monograph to arguing that the margin of appreciation (and deference more generally) ought to be regarded as doctrines, in the same way that 'fair, just and reasonable' in the context of English tort law is - as both provide an 'amorphous set of standards'.

19 This distinction naturally embodies legal scepticism that is familiar from legal realist and critical legal studies modes of analysis. However, for the purposes of this paper it is unnecessary to accept the theoretical assumptions of these discourses at large. No position is being taken on the question of whether all legal doctrines are best explained by looking for an ideological or sociological explanation. Instead, regardless of what position one takes on these fundamental questions, the suggestion is merely that the margin of appreciation is used in a way that lends itself to particular scepticism, and that this in turn reveals something interesting about the conflicting strands of the Court's institutional identity.

20 The application of the concept of a tool to the margin of appreciation is not entirely novel, nor is the extent of my critique of the justifications given for it. It was described by Judge Malinverni in Lautsi $v$ Italy as a 'a tool that needs to be handled with care' (see Lautsi $v$ Italy (2011) 54 EHRR 3 (GC), dissenting opinion of Judge Malinverni, joined by Judge Kalaydjieva on page 1, quoted in Dean Spielmann, 'Allowing the Right Margin: The European Court of Human Rights and the National Margin of Appreciation Doctrine: Waiver or Subsidiarity of European Review?' (2012) 14 Cambridge Yearbook of European Legal Studies 381, 383). It has been argued that it is a 'practical tool enabling the Court to evade its responsibilities' (Paul Mahoney, 'Marvellous Richness of Diversity or Invidious Cultural Relativism?' (1998) 19 Human Rights Law Journal 1), and leading practitioners at the Court have criticised its unpredictability, lack of legal certainty and potential for abuse (see Lester (n 14)).
} 
inquiry into the politics of its varied uses, as it invites such scepticism even from those for whom such critiques are exceptional. The positioning of the margin of appreciation as a canon of the Court's interpretive techniques is all the more striking when one considers that some of the most vehement objections have come from the bench itself. ${ }^{21}$ What is the origin of this opposition? The following section provides three bases on which the reasons given for justifying the use of the margin are invariably unsatisfying, for want of clarity. The aim is to suggest that opposition to the margin of appreciation need not be ideologically motivated, but can arise from frustration with the paucity of reasoning employed in its use, and the subsequent costs this may impose on legal certainty and the Court's legitimacy.

\subsection{Three flexible uses: inconsistent use of state practice, natural kind reasoning and ad hoc reliance on expertise}

This part of the paper proposes three aspects of the Court's use of the margin of appreciation that suggest it is being used more as a 'flexible tool' than on a principled basis. All three of these refer to reasons given by the Court for setting a wide or narrow margin of appreciation. It is important to note that in many cases this is the decisive moment. While there are exceptions, the general rule is that when the Court grants the State a wide margin, this precedes a ruling in favour of the State. ${ }^{22}$ When the State is granted a narrow margin, the applicant usually succeeds. ${ }^{23}$ The factors that contribute to the setting of the margin, then, are of crucial importance.

${ }^{21}$ See, for example, Judge De Meyer's dissent in $Z v$ Finland: '[it is] high time for the Court to banish that concept from its reasoning. It has already delayed too long in abandoning this hackneyed phrase and recanting the relativism it implies.... The empty phrases concerning the State's margin of appreciation... are unnecessary circumlocutions, serving to illustrate that States may do anything the Court does not consider incompatible with human rights' ( $Z v$ Finland (1998) 25 EHRR 371. Spielmann (n 20) 392-394 provides further examples of judicial criticism of particular uses of the margin.

22 See Hirst $v$ United Kingdom (No 2) (2006) 42 EHRR 41 for an example of a case in which the State was granted a wide margin of appreciation, yet the impugned practice was still held to have fallen outside 'any acceptable margin of appreciation', attracting much criticism. In section 3.2 below, it is suggested that this peculiar use arose from a tension between the Court's commitment to recognising consensus and State practice, and its clear preference for the practice of certain States that are in greater conformity with its image of an ideal liberal democratic society.

23 See Lautsi $v$ Italy (n 20), dissenting opinion of Judge Malinverni, on page 1, Where the court decrees that the margin of appreciation is a narrow one, it will generally find a violation of the Convention; where it considers that the margin of appreciation is wide, the respondent state will usually be "acquitted"'. This is analogous to the distinction between 'rational basis', 'strict scrutiny' and 'intermediate' review in US constitutional law. As in the case of the margin, it has been argued that these standards of review involve a spectrum. See Richard H Fallon Jr, 'Strict Judicial Scrutiny' (2007) 54 UCLA L Rev 1267, 1294-96, 1330-30, for the argument that the strict scrutiny standard involves important commonalities' with proportionality assessments, such as those used by the European Court. 


\subsubsection{Inconsistent use of State practice: the consensus standard}

The most common justification for setting the width of the margin of appreciation is the existence or non-existence of consensus among the Member States, either as to the relevant importance of the interest at stake, or how best to protect it. ${ }^{24}$ This justification has found support in many scholarly defences of the margin, as being necessary in light of the treaty-based origins of the Court, and its commitment to interpreting the Convention as a 'living instrument'. ${ }^{25}$ Whatever normative position one takes on this justification, it is clear that it represents a feature of the jurisprudence that can lead to a decisive outcome.

Yet it is striking how little attention is paid in the judgments to this profoundly important moment in each case. Whether or not there is sufficient or inconsistent consensus is, according to the Court, the decisive moment - as from this follows either a wide (the State wins) or narrow (the State loses) margin of appreciation. But despite this, there have been no attempts to systematically establish criteria that might aid practitioners to determine both when consensus is present, and when consensus counts decisively. ${ }^{26}$ For example, in Dickson $v U K$, a case concerning the compatibility with the Convention of providing artificial insemination facilities for prisoners, more than half the States allowed the practice, yet this was insufficient to make restricting it a breach of the applicant's article 8 rights. ${ }^{27}$ By contrast, in Hirst (No 2) $v$ United Kingdom, a case concerning restrictions on the rights of prisoners to vote in democratic elections, seven other States exhibited the same practice as the UK in automatically disenfranchising incarcerated prisoners, and eight States imposed more extensive restrictions on the rights of prisoners. ${ }^{28}$ Despite this, the Court held that the UK's practice was a violation of the appli-

\footnotetext{
24 See Dickson v UK (2008) 46 EHRR 41, para 78: 'Where, however, there is no consensus within the Member States of the Council of Europe either as to the relative importance of the interest at stake, or how best to protect it, the margin will be wider. This is particularly so, where the case raises complex issues and choices of social strategy: the authorities' direct knowledge of their society and its needs means that they are in principle better placed than the international judge to appreciate what is in the public interest'.

25 See Legg (n 11) ch 5, and Yukata Arai-Takahashi, 'The Margin of Appreciation Doctrine: A Theoretical Analysis of Strasbourg's Variable Geometry' in A Follesdal, B Peters and G Ulfstein (eds), Constituting Europe: The European Court of Human Rights in a National, European and Global Context (CUP 2013). However, see Benvenisti (n 14) for the criticism that relying on consensus is illegitimate as it results in a breach of the Court's duty as a human rights organ.

26 See Brauch (n 14) 135 for the argument that the lack of clarity concerning the European consensus standard represents a threat to the rule of law, as it is 'not an effective predictor as to how the court will resolve any particular case'.

27 Dickson v United Kingdom (n 24).

28 Hirst (No 2) $v$ United Kingdom (n 22). See section 3.2 'The margin of appreciation and the Court's unarticulated discrimination between Member States', below, for further analysis of this case.
} 
cant's rights under article 3 Protocol $1 .{ }^{29}$ Likewise, in Handyside, the Court held that there was no uniform European consensus on morals, and therefore the UK's practice in restricting publication of a book was consistent with its Convention obligations, despite the fact that the book was freely available across Europe. ${ }^{30}$ The case law is replete with examples of the standard being used in ad hoc and sometimes contradictory ways, with no explanation of why it is decisive in some cases, and yet is not even relied on in others. ${ }^{31}$

The consensus standard thus fails to provide a principled basis for the Court's use of the margin of appreciation. The Court sometimes analyses systematically the practices of various Member States to support a finding of consensus - but on other occasions, it fails to do so, or disregards such findings, even when presented by the applicant. The Court's unwillingness to apply this aspect of the test in a systematic way suggests that the requirement for flexibility is prioritised over the search for a principled basis. That the practice of European States via consensus could fail to provide such a basis is unsurprising when one considers the countervailing claims of human rights, which suggest that the practice of some States, those with stronger traditions of respecting human rights, must count for more than that of others. This arises from the tension at the heart of the European Court, and its twin commitments to the ideas of a treaty-based system composed of formally equal States, and the transnationalism of human rights, which essentially undercuts this equality. As a principled basis for the margin of appreciation, then, the consensus standard is unlikely to succeed and its ad hoc use contributes to the perception of the margin as a tool, invoked for other reasons than the justifications found in the text of the judgments. ${ }^{32}$

29 Hirst (No 2) $v$ United Kingdom (n 22) para 41.

30 Handyside $v$ United Kingdom (n 6) 57.

31 Brauch (n 14) 145, 'a "European consensus" provides no predictability for decisions. It does not tell individuals or governments when a state action becomes a Convention violation'. Yourow (n 5) 79 also criticises the consensus standard as failing to offer full reasoning for the Court's determination of the presence or absence of a consensus: 'The problem with the standard, as set out in the opinions, starting with Belgian Linguistics, is that the style of sparse opinion writing allows for only a very rare exposition of the components of the consensus. The Court, as here, simply states that a consensus of member states national law and practice exists, and leaves its conclusion unsupported by discussion, example or reference of any kind to any specific national law or practice!'

32 The enlargement of the Convention system and the accession of Eastern European States with weaker traditions of human rights protection following the collapse of the Soviet Union pose an obvious challenge to this justification for the margin of appreciation that the jurisprudence has failed to accommodate in a principled way. See section 3.2 'The margin of appreciation and the Court's unarticulated discrimination between Member States' below. 


\subsubsection{Reliance on natural kind reasoning}

The second problematic technique the Court uses to set the margin of appreciation may be described as an over-reliance on 'natural kind' reasoning. This critique is based on an idea found in the philosophy of the social sciences. ${ }^{33}$ 'Natural kinds' are concepts that are so basic that they correspond straightforwardly with features of the natural world, and as such they can be said to 'carve nature at its joints'. ${ }^{34}$ The idea is that the Court sometimes asserts an analytical category that it argues is relevant to the dispute, then claims that that category entails either a necessary absence of consensus justifying a wide margin, or a subjectmatter that is best left to the discretion of Member States. Yet the Court is being asked to determine whether the specific government act in question constitutes an unjustified interference with a Convention right, not the relationship between an abstract analytical category and the concept of consensus. There is thus a circularity present that suggests an unwillingness to engage in a detailed analysis of the interests at stake.

For example, in freedom of expression cases, the State often seeks to justify its infringement of a right based on the 'public morals' exception in article 10(2), which permits States to interfere with the right for the 'protection of public morals', to the extent that the interference is 'necessary in a democratic society'. ${ }^{35}$ Thus the key question the Court is often asked to determine is whether the respondent State is justified in invoking the public morals exception, or whether the restriction on freedom of expression is justified for the protection of public morals.

\footnotetext{
33 See Jerry A Fodor, 'Special Sciences: (or: the Disunity of Science as a Working Hypothesis)' (1974) 28 Synthese 97.

34 The origins of this phrase date back to Plato in his 'Phaedrus' 265e, where in a discussion of systems of classification Socrates says, 'The second principle is that of division into species according to the natural formation, where the joint is, not breaking any part as a bad carver might' (see Plato, Phaedrus (Robin Waterfield tr, Oxford World's Classics 2003). In Alexander Bird and Emma Tobin, 'Natural Kinds' in Edward N Zalta (ed), The Stanford Encyclopedia of Philosophy (Spring 2016), the concept is explained as follows: 'Mill's descriptivism implies that for each natural kind term there is an associated set of properties such that for some item to be a member of that natural kind, it should possess those properties - these are properties that describe the kind in question... someone who understands the term adequately will grasp a priori that something falls under the kind term if and only if it satisfies that description. For example, as mentioned above, Kant held the view that it is a priori that something falls under the kind term gold only if it is a yellow metal...'<http:// plato.stanford.edu/archives/spr2016/ebtries/natural-kinds/> accessed 30 May 2016.

35 European Convention on Human Rights (n 3) art 10(2): "The exercise of these freedoms, since it carries with it duties and responsibilities, may be subject to such formalities, conditions, restrictions or penalties as are prescribed by law and are necessary in a democratic society, in the interests of national security, territorial integrity or public safety, for the prevention of disorder or crimes, for the protection of health or morals, for the protection of the reputation or rights of others, for preventing the disclosure of information received in confidence, or for maintaining the authority or impartiality of the judiciary'.
} 
Yet the approach the Court takes is simply to assert that it is not possible to find in the domestic law of the Contracting States a uniform European conception of morals', and then to proceed to set a wide margin of appreciation. ${ }^{36}$ It thus accepts the States' assertion of the public morals exception as though 'morality' were a natural kind, yet without conducting any systematic investigation into the actual practices of the relevant Member States. The Court simply asserts that the issue is a moral one, and then proceeds to state that, because it is a question of morality, morality is an area in which there is necessarily no European consensus, and thus the margin of appreciation is very wide, and so the practice is legitimated.

This can be contrasted to Dudgeon $v$ United Kingdom, a case concerning the criminalisation of homosexual acts in the UK. Here, the Court took the opposite approach, and whilst accepting that the question was one of morality, held that there was a European consensus reflecting the particular practice of homosexual acts. Likewise, in Dickson, the Court asserted the natural kind of a 'particularly important facet of a person's existence or identity', and argued that where such a facet is at stake the State's margin of appreciation will be very narrow. ${ }^{37}$ Yet it is hard to imagine, in the context of a breach of a Convention right, a circumstance which is not such a particularly important facet. For example, why in cases involving derogations on the grounds of national security, where the State seeks to justify restrictive measures such as extended detention without trial periods, is the margin wide, despite the fact that the interests in question are undoubtedly important? Surely the very question the Court is being asked to determine, in both cases, is the content of categories such as 'public morals' or 'particularly important facets of a person's existence or identity'.

The Court's technique in such cases can be characterised as follows: the assertion of a vague analytical category, as though it were a natural kind, with no attempt to articulate the boundaries of that category, accompanied by the assertion that there is a necessary connection between that category and the width of the margin, from which flows the inevitable result of the case. This again suggests an instance in which the margin of appreciation is being wielded as a flexible tool, and as a

\footnotetext{
36 Handyside $v$ United Kingdom (n 6) para 48. In this case, this led the Court to find that it was within the House of Lords' margin of appreciation to find that restricting publication of the Little Red Book was necessary for the protection of public morals, despite the fact that it had already been published in other European States and was freely available across Europe.

37 Dickson v United Kingdom (n 24) para 78: 'Accordingly, when a particularly important facet of an individual's existence or identity is at stake (such as the choice to become a genetic parent), the margin of appreciation accorded to a State will in general be restricted' (emphasis added).
} 
substitute for detailed reasoning as to the importance of the interests at stake. $^{38}$

\subsubsection{Ad hoc reliance on expertise}

Another common justification the Court relies on in allowing the State a wide margin of appreciation is the superior 'expertise' of the national authorities. ${ }^{39}$ The idea is that the national authorities, especially in circumstances when there is no European consensus (although it is unclear how these two ideas are connected) are better placed to assess the factual or legal circumstances of the case. ${ }^{40}$ The Court sometimes uses evocative, though opaque, language such as 'by reason of their direct and continuous contact with the vital forces', State authorities are 'in principle' better placed than the international judge to give an opinion on the exact content of those requirements. ${ }^{41}$ This principle has a powerful intuitive appeal, and one that has found support from scholars who defend the margin of appreciation. Yet, if true, it is not clear what relevance it should have to the outcome of a case. For, if true, it is true of every case, all of which involve striking a balance between conflicting rights and interests, yet only in some cases is the margin set widely, and only in some is the 'expertise' argument relied on.

Likewise, the importance of this contact is never explained. If the role of the Court included determining factual issues, the superior expertise of the national authorities might be more obvious. Yet the Court is an international human rights tribunal, and in every case its task is the same: it inevitably involves the balancing of different rights, either against one another, or some public interest justification. If the national authorities are better placed to make such determinations then this would seem to deprive the Court of its function - and it is difficult to see why the argument should apply in some cases, but not in others.

\footnotetext{
38 See Section 4 below "Judicial rulership and the politics of separation of powers' for the argument that if the margin is being used as an avoidance mechanism for dealing with a particularly controversial question, then such an approach is bound to fail, as when using the margin the Court cannot help but take a stake in the substantive conflict and render a decision with decisive legal effect in favour of the State practice.

39 See Legg (n 12) ch 6 for a thorough analysis of the Court's jurisprudence on expertise, and an attempt to categorise the different situations in which this is relied on.

40 See Dickson $v$ United Kingdom (n 12) para 78: 'This is particularly so where the case raises complex issues and choices of social strategy: the authorities' direct knowledge of their society and its needs means that they are in principle better placed than the international judge to appreciate what is in the public interest. In such a case, the Court would generally respect the legislature's policy choice unless it is "manifestly without a reasonable foundation." There will usually be a wide margin accorded if the State is required to strike a competing balance between private and public interests or Convention rights'.

41 Handyside $v$ United Kingdom (n 6) 48.
} 
The absence of deep analysis and ad hoc usage of the expertise justification again suggest that the margin of appreciation operates more as a discretionary tool than a doctrine deployed on a principled basis. Yet regarding it as a tool for the Court to 'evade its responsibilities' diverts attention away from a full consideration of its effects. ${ }^{42}$ For when the margin of appreciation is used, it renders the outcome of a case decisively in favour of one party, in a manner that can have far-reaching effects within the States concerned, leading to changes in legislation, or even constitutional amendments. ${ }^{43}$ As such, neither the attempt to reify the margin of appreciation as a doctrine operating on a principled basis, nor its reduction to an ad hoc and arbitrary affront to the rule of law, is satisfactory. Both approaches seem to ignore the crucial governance effects of the use of such a tool. The following sections offer sketches of how we might begin to think about the margin of appreciation in these terms.

\section{Governance effects of the margin of appreciation}

\subsection{The politics of the margin of appreciation qua capture of the international constitutionalisation process}

One way of identifying the political stakes involved in international human rights adjudication, and the governance effects of the Court's use of the margin of appreciation, is to situate it in the context of broader debates concerning international constitutionalisation. This section begins by setting out this context, identifying the European Court of Human Rights as one possible actor among many in a process of generating constitutional norms that have a widespread effect. It is suggested that the political stakes in human rights adjudication involve the clash between alternative visions of constitutionalisation: the traditional nation-state model, and other approaches, such as that of systems theory, which are more accommodating of norm generation outside the reach of States. These political stakes arise from substantive issues being framed as human rights issues in the first place. It is argued that a governance effect of the margin of appreciation is to take a stake in this conflict, by capturing issues as 'human rights issues' and reverting regulatory authority back to the State, away from private actors. ${ }^{44}$

\footnotetext{
42 Mahoney (n 20).

43 Wheatley (n 17) 157-161.

44 This section can be seen in the context of broader debates concerning the legitimacy of public and private models of regulation in global governance, such as, for example, Matthias Goldmann, 'A Matter of Perspective: Global Governance and the Distinction between Public and Private Authority (and Not Law)' (25 January 2015) <http://ssrn.com/ abstract $=2260293>$ accessed 2 December 2016. For the purposes of this paper, it is not necessary to argue in favour of public or private authority per se in global governance. The suggestion is merely that such a conflict does exist, and that the margin of appreciation has the effect of taking a stake in it.
} 
Scholars of international law and global governance have in recent years responded to the phenomena of a proliferation of regulation covering a variety of spheres of activity, and a disaggregation of rule-making power among both private and public actors and institutions. ${ }^{45}$ In Kennedy's striking phrase, the world is 'covered in law', and the task of identifying who generates the background rules which structure much of modern commercial, social and public activity is an essential step in identifying (and thus contesting) how law is used to wield power in contemporary global governance. ${ }^{46}$ The stakes involved in acquiring and maintaining such regulatory power, then, are high, and an analysis of international human rights adjudication via the European Court must be able to situate it within this broader context. ${ }^{47}$ Whilst the role of the European Court in the generation of constitutional norms has been considered, this has mainly occurred via an analysis of the Court's 'dialogue' with public domestic institutions. ${ }^{48}$ This paper differs in that it seeks to assess the politics of the margin of appreciation in terms of

45 For example, Martti Koskenniemi argues that existing public international law doctrines of treaty interpretation offer the means for resolving clashes of regulatory capacity: see 'Fragmentation of International Law: Difficulties Arising from Fragmentation and Diversification of International Law' (18 July 2006, Report of the International Law Commission, 58th Session 1 May - 9 June and 3 July - 11 August 2006, UN Doc. A/CN.4/7.702). Gunther Teubner and Andreas Fischer-Lescano, 'Regime Collisions: The Vain Search for Legal Unity in the Fragmentation of Global Law' (2004) 25 Michigan. J Intl L 999 suggest that disaggregation and legal pluralism is the inevitable result of an international society organised into discrete sectors, and offer a sceptical view about the prospect of international harmonisation of legal norms. Benedict Kingsbury and others, 'Forward: Global Governance as Administration - National and Transnational Approaches to Global Administrative Law' (2005) 68 Law \& Contemporary Problems 1 introduce the prospect of a global administrative law as resolving the potential legitimacy crisis of disaggregation of regulatory power. David Kennedy suggests a focus on the experts who generate these rules, whether in public or private institutions, as a means of rediscovering the politics of the 'background rules' of global governance. See David Kennedy, 'The Julius Stone Memorial Address 2004 at the Julius Stone Institute of Jurisprudence, University of Sydney: Challenging Expert Rule: The Politics of Global Governance' (2005) 27 Sydney L Rev 5.

46 Kennedy (n 45) 3: 'In our world, power lies in the capillaries of social and economic life. Myriad networks of citizens, commercial interests, civil organisations and government officials are more significant than interstate diplomacy'.

47 That law can have such a global governance effect can be seen by the renewed focus on the European Union's power to export legal norms around the world. For example, Slaughter and Burke-White argue that the EU exerts power over States by offering a new model of international norm generation that focuses on a close interaction with the Member States, encouraging them to develop domestic law in accordance with ends that are specified inter-governmentally. See Anne-Marie Slaughter and William Burke-White, The Future of International Law Is Domestic (or, the European Way of Law)' (2006) 47 Harvard Intl L J 237. Likewise, Bradford suggests that the EU's global power is frequently underestimated, as its 'Brussels Effect' has a strong capacity to force other states to adopt its own regulatory standards when entering into trade agreements: see Anu Bradford, 'The Brussels Effect' (2012) 107 Northwest University L Rev 1.

48 See Anne-Marie Slaughter, ‘Judicial Globalization' (2000) 40 Virginia J Intl L 1103 for an example. 
broader processes of constitutionalisation among both private and public actors.

One way of understanding this potential clash is by assessing the role of the European Court in light of what might be termed 'post-statist' models of international constitutionalism, of which Teubner's 'societal constitutionalism' and 'systems theory' offer a prominent example. ${ }^{49} \mathrm{Un}$ der these models, international society can be seen as divided into a discrete set of functionally differentiated autonomous social systems, which compete to occupy the same regulatory space, in a process occurring both inside and outside the context of the nation-state. ${ }^{50}$ As such, it is easy to see how the European Court of Human Rights clashes with such a model. It is closely aligned with the traditional trajectory for developing constitutional norms, via the public institutions of its Member States. But there is no reason a priori why the emerging constitutional norms of this trend of constitutionalisation ought to be generated by this trajectory of domestic legislature, domestic court, and international human rights court. ${ }^{51}$ Indeed, this would involve normative assumptions about the function of the nation-state that ought not to be conceptualised as somehow logically connected with the process of constitutionalisation. Such a model is highly contingent, and carries with it costs and benefits, which ought to be assessed as part of understanding the politics of international human rights adjudication.

It follows that framing an issue as a human rights issue and bringing it within the scope of the European Court's jurisdiction can have the effect of increasing the Court's (and thus that of the Member States with whom the Court is in dialogue) constitutionalising capacity at the expense of the autonomous sub-fields of international society. ${ }^{52}$ This process is

\footnotetext{
49 See Gunther Teubner, 'Societal Constitutionalism: Alternatives to State-Centered Constitutional Theory' in Christian Jeorges and Inger-Johanne Sand (eds), Transnational Governance and Constitutionalism (Hart 2004); and Teubner and Fischer-Lescano (n 45).

50 Teubner (2004) (n 49) 5: The constitution of world society comes about not exclusively in the representative institutions of international politics, nor can it take place in a unitary global constitution overlying all areas of society, but emerges incrementally in the constitutionalisation of a multiplicity of autonomous subsystems of world society'.

51 Of course, there are a variety of political theory arguments one could produce in support of this model, perhaps founded primarily on its comparative democratic, or other, legitimacy (see A Follesdal, JK Schaffer and G Ulfstein (eds), The Legitimacy of International Human Rights Regimes: Legal, Political and Philosophical Perspectives (CUP 2015) for various attempts to develop legitimising arguments in this context). The purpose of this section is merely to suggest that the triumph of one model is accompanied by costs and benefits that ought to be assessed, not taken as a base-line presumption.

52 Teubner ( $\mathrm{n}$ 49) provides the example of internet freedom, which he supports with this striking quote from the Declaration of Independence of Cyberspace: 'Governments of the Industrial World, you weary giants of flesh and steel... the global social space we are building to be naturally independent of the tyrannies you seek to impose on use. You have no moral right to rule us nor do you possess any methods of enforcement we have true reason to fear'.
} 
facilitated by certain essential features of human rights adjudication in the Convention context: the substantive minimalism of the rights in the treaty text, making them flexible tools for advocates to apply to a broad variety of situations; the Court's 'living instrument' approach, whereby it interprets the Convention in light of modern day circumstances to constantly expand the scope of its protection; the doctrine of 'horizontal effect', whereby Convention rights can impose obligations on private actors governing their interactions with one another; and the possibility of the Court interpreting a Convention right as entailing a 'positive obligation' for States to bring about conditions for its realisation. ${ }^{53}$

We can see examples of this clash in innovative, autonomous spheres of the international economic and commercial order, such as international commercial arbitration. ${ }^{54}$ To imagine how a clash might occur in this context, suppose that in a domestic court in a Convention state an advocate raises the article 6 argument that some aspect of an arbitration deprived the client of the right to a fair trial. ${ }^{55}$ Suppose the matter proceeds

\footnotetext{
53 The 'living instrument' approach is analysed in Letsas (n 13). An example of the 'horizontal effect' of Convention rights can be seen in the UK in cases such as Campbell $v$ MGN (per Baroness Hale, paras 132-135), where art 8 jurisprudence from the European Court led to the development of a general tort of invasion of privacy in English law, thus affecting the rules that govern the extent to which a group of private actors (the press) could regulate itself (Campbell v MGN [2004] UKHL 22). An example of the Court recognising the 'positive obligations' on Member States to develop their laws so as to generate better conditions for the protection of Convention rights can be found in the art 9 (freedom of thought, conscience and religion) jurisprudence. See Jean-François Akandji-Kombe, Positive Obligations Under the European Convention on Human Rights (Human Rights Handbook no 7, 2007) <www. echr.coe.int/LibraryDocs/DG2/HRHAND/DG2-EN-HRHAND-07(2007).pdf> accessed 30 May 2016.

54 International commercial arbitration is a dispute mechanism premised around the ideas of party autonomy. Insofar as possible, it is supposed to sit outside the context of nation-state regulation, so as to avoid litigants being disadvantaged by the imposition of foreign laws in cross-border disputes: see Tibor Varady, John J Barcello III and Arthur T Von Mehren, International Commercial Arbitration: A Transnational Perspective $\left(5^{\text {th }}\right.$ ed, West 2012) 2 .

55 There are multiple examples of this occurring, both in the context of the enforcement of arbitration awards and irregularities in the arbitration proceeding itself. See, for example, Regent Company $v$ Ukraine App no 773/0 (ECtHR 2008) where Ukraine was held to have violated art 6 by refusing to enforce an arbitral award; Stran Greek Refineries $v$ Greece (1995) 19 EHRR 293, where legislation retroactively invalidating an arbitration award was found to be a breach of art 6; and in a recent Paris Court of Appeal case, where the Court held that arbitral tribunals are not exempt from applying the right of access to justice, as delimited by art 6 and the Convention jurisprudence: see Cour d'appel [CA] [regional court of appeal] Paris, 1e ch, 17 Nov 2011, no 09/24158, quoted in Jaroslav Kudrna, 'Arbitration and Right of Access to Justice: Tips for a Successful Marriage' (2013) New York University Journal of International Law Online Forum <http://nyujilp.org/wp-content/uploads/2013/02/ Jaroslav-Kudrna-Arbitration-and-Right-of-Access-to-Justice-NYU-JILP-Feb-2013.pdf> accessed 30 May 2016. There, examples suggest that whilst the European Court can constrain States' ability to interfere with the arbitration process via prevention of enforcement, at the same time it can use art 6 to interfere with that independence by increasing their power to regulate the conduct of arbitral proceedings.
} 
to the European Court, and the bench is persuaded by the argument. The Court then generates case law about the circumstances in which that aspect of international commercial arbitration proceedings breaches article 6. This jurisprudence then filters down into the national legal orders, not just in the respondent State, but through the Convention system at large, and has a constitutionalising effect that impinges upon the autonomy of the field of international commercial arbitration.

Thus the political stakes in international human rights adjudication can be described as capture of the constitutionalisation process. This is an aspect of the politics that is often missed, as for practitioners and theorists working from within the field of human rights it is hard to identify the framing of an issue as a human rights one as political at all. Yet the politics lie in the fact that it shifts power to certain institutions (both the European Court itself and the public institutions of the Member States), and towards those groups that might be better able to mobilise its architecture in pursuit of their own interests. ${ }^{56}$ And this capture takes a stake in the unfolding process of international constitutionalisation, by favouring the traditional nation-state model over new approaches such as 'systems theory' and 'societal constitutionalism', which recognise the legitimacy of autonomous, transnational groups in generating constitutional norms outside that context. What role, then, does the margin of appreciation play in this? If this is a key aspect of the politics of international human rights, does the margin favour one path of international constitutionalisation, or is it a neutral tool, the effects of which depend upon the particular circumstances?

One prima facie response might be to regard the margin as a means of limiting the Court's jurisdiction. The identification of the margin of appreciation with other doctrines of deference, and the justification based on the relative 'expertise' of the State body, suggest that we ought to regard its effect as imposing a limitation on the constitutionalising capacity of human rights. ${ }^{57}$ However, further consideration suggests that its

\footnotetext{
56 The ability of NGOs to mobilise the institutional architecture of the European Court of Human Rights has been analysed in detail by Rachel Cichowski, in 'Civil Society and the European Court of Human Rights' in Jonas Christoffersen and Mikael Rask Madsen (eds), The European Court of Human Rights: Between Law and Politics (OUP 2011). Most striking is her finding that there is a 'mobilization-litigation' dynamic that has led NGOs to increase their capacity to mobilise the European Court of Human Rights to pursue their social policy goals, suggesting the possibility of capture of the Court itself by groups best able to use it. It is also worth commenting that these groups may not be equally distributed across the Member States, suggesting that states with more developed civil society organisations might exert greater control over the development of European human rights jurisprudence than States with less strong civil society traditions.

57 See Legg (n 12) ch 6 for an analysis of the expertise justification, suggesting that the greater expertise of national decision-makers is a less controversial factor for the Court to take into account when deciding whether to grant the state a wide margin of appreciation.
} 
governance effect is more nuanced. For when the Court grants the State a wide margin of appreciation, it does not rule that it has no jurisdiction over the substantive matter. Indeed, the other institutional characteristics outlined above (the minimalist nature of human rights norms, and the Court's 'living instrument' interpretive approach) suggest a phenomenon of ever increasing scope of application. What tools, then, does the Court have to limit this expansion of its capacity? The margin of appreciation is not such a tool, as the effect of a wide margin is not to render the issue one outside the scope of human rights. Rather, even when the Court defers to the Member State, it resolves the issue decisively in favour of the State's interpretation of its human rights obligations vis-à-vis the substantive issue. It has a legal effect, and generates human rights case law around the substantive issue that can be used by future litigants to expand or limit the scope of the right, thus reverting constitutionalising capacity over the underlying field back to the State, and exporting it to other Member States via the jurisprudence of the European Court.

As such, one way of analysing the political stakes involved in international human rights adjudication is by assessing the costs and benefits of framing an issue as a human rights issue, in light of different potential paths of constitutionalisation. The margin of appreciation is not neutral in this conflict, but takes a stake, by reverting constitutionalising capacity back to the Member States, even where the Court grants the State a wide margin of appreciation. An understanding of the governance effects of the margin of appreciation, then, would involve a detailed examination of the costs and benefits of the politics of nation-state models of regulation. To what extent do they impinge on the autonomy of private actors? Are some groups, or even states, better able to mobilise this institutional machinery than others? The answers to these questions might aid in assessing the margin of appreciation in light of other doctrinal possibilities for limiting the Court's jurisdiction, and its compatibility with other key aspects of the institutional and jurisprudential context, such as the remarkable flexibility of human rights norms, and the Court's commitment to interpreting the Convention as a 'living instrument'.

\subsection{The margin of appreciation and the Court's unarticulated discrimination between Member States}

The European Court of Human Rights has been criticised for discriminating against some members by issuing harsher judgments against newly joined or developing States compared to the original Western European members from stronger liberal democratic traditions. ${ }^{58}$ The purpose

58 See Shai Dothan, 'Judicial Tactics in the European Court of Human Rights' (2011) 12 Chicago $\mathrm{J}$ Intl L 115, 116. Of course, this difference in treatment poses significant challenges for measurement. However, Dothan offers several different examples to support the 
of this section is to assess the use of the margin of appreciation in light of this critique. It is suggested that an alternative way of thinking about this criticism is via the inconsistent use of the 'consensus standard' for setting the margin of appreciation. It will be argued that this inconsistent use is unsurprising, as the unarticulated discrimination arises from a tension between the two aspects of the Court's institutional identity that pull in opposite directions: the teleological claims of universal human rights, and the strong association of those claims with liberal democratic traditions, against the formal commitment to equality of Member States arising from the treaty-based system. The case of Hirst $v$ United Kingdom (concerning restrictions on prisoners' voting rights) is provided as an example of how this institutional conflict poses a challenge for the margin of appreciation, and led to an application of it that has attracted much criticism. ${ }^{59}$ It is argued that the strange result in this case can be explained by the Court's unarticulated discrimination between Member States, and its preference for the practice of States from strong liberal democratic traditions.

As mentioned above, the Court's finding that there is a presence or absence of European consensus on a particular practice can be the

claim of differing treatment. He compares the Court's behaviour towards Russia and England, arguing that the Court has mounted an 'extended campaign' against Russia regarding its military operations in Chechnya, involving over one hundred judgments issued against the State. By contrast, he suggests that when the Court's judgment in Osman $v$ United Kingdom attracted harsh academic criticism (including from leading human rights scholar Conor Gearty) the Court retreated from its former position in a subsequent judgment, $Z$ and Others $v$ United Kingdom (see Dothan, ibid, 136-137). He also compares the treatment of Ireland and Greece in the Court's analysis of the grounds for derogating from the Convention in times of national emergency, arguing that in Lawless $v$ Ireland the State was granted a wide margin of appreciation, yet in The Greek Case, the margin was narrow (Dothan, ibid, 138). A final example concerns the difference in treatment regarding the Court's jurisdiction, where he contrasts Bankovic and Others $v$ Belgium and Others, a case in which the Court interpreted its jurisdiction narrowly to find no violation of the Convention where the claim was brought against seventeen NATO members for civilian deaths during airstrikes, with analogous cases where the Court gave a contrary finding of jurisdiction against Turkey and Moldova as respondent States (see Loizidou v Turkey (Preliminary Objections) and Ilascu $v$ Moldova and Russia, Dothan, ibid, 139-140).

59 The strongest criticism can be found in the five-judge dissent. In Judge Costa's separate opinion, he suggests that the majority's use of the margin of appreciation embodies a fundamental confusion, in granting the State a very wide margin of appreciation following its analysis of State practice, yet ultimately concluding that the State was in breach: 'However, once I had rejected that approach and accepted that the States have a very wide margin of appreciation to decide on the aims of any restriction, limitation or even outright ban on the right to vote... how could I, without being inconsistent, reduce that margin when it came to assessing the proportionality of the measure restricting universal suffrage (a concept which, of course, remains the democratic ideal)?' Hirst $v$ United Kingdom (n 22), dissenting opinion of Judge Costa, at 5. It is worth noting that some commentators have welcomed the Court's judgment, as an indication that it is no longer considering itself to be bound by consensus (see George Letsas, A Theory of Interpretation of the European Convention on Human Rights (OUP 2009). 
decisive moment in many cases. This is because a finding of an absence of consensus leads to a wide margin of appreciation, which has almost invariably resulted in a victory for the State. Given this, it is striking that the Court has failed to develop systematic principles for its assessment of State practice to underpin the consensus justification. The reconceptualisation of the margin of appreciation as a tool suggests that the absence of a clear theoretical framework might offer the Court greater flexibility in using the margin to resolve a dispute decisively. However, this absence of principled bases might also be understood in another way: as the expression of an unarticulated, though fundamental, aspect of the Court's institutional identity via a preference for the practice of some States over that of others.

Although the margin of appreciation and the consensus justification appear to reflect the commitment to the formal equality of the Member States that underpins the treaty-based origins of the Convention system, in practice this is not the reality. This is apparent from judgments such as Hirst $v$ United Kingdom. In that case, the Court found that the UK had breached Article 3 Protocol 1 of the Convention (the right to free elections) by automatically removing the right to vote from prisoners. That the majority judgment attracted a five-judge dissent and troubled many commentators arises from the fact that its use of the margin of appreciation took a novel form.

The respondent State raised the argument that the State's margin of appreciation was very wide in the sphere of electoral arrangements, and cited numerous other cases in which the Court had recognised this. It then argued that the particular practice in question (automatic disenfranchisement) was not contrary to European consensus, and in fact was supported by the practice of many other States. According to the UK Government's survey, eighteen States allowed prisoners to vote without restriction, but in twenty-five others the right was restricted in some way, including thirteen who shared the UK's practice of automatically disenfranchising all prisoners. ${ }^{60}$ The Divisional Court in the UK proceedings found that eight Convention States imposed greater restrictions on the right than the UK (either by barring from democratic participation for

\footnotetext{
60 See Hirst $v$ United Kingdom (n 22) para 33: 'According to the Government's survey based on information obtained from its diplomatic representation, eighteen countries allowed prisoners to vote without restriction (Albania, Azerbaijan, Croatia, the Czech Republic, Denmark, Finland, "the former Yugoslav Republic of Macedonia”, Germany, Iceland, Lithuania, Moldova, Montenegro, the Netherlands, Portugal, Slovenia, Sweden, Switzerland and Ukraine), in thirteen countries all prisoners were barred from voting or unable to vote (Armenia, Belgium, Bulgaria, Cyprus, Estonia, Georgia, Hungary, Ireland, Russia, Serbia, Slovakia, Turkey and the United Kingdom), while in twelve countries prisoners' right to vote could be limited in some other way (Austria, Bosnia and Herzegovina, France, Greece, Italy, Luxembourg, Malta, Norway, Poland, Romania and Spain)'.
} 
life or after parole for certain offences) ${ }^{61}$ As such, it was not open to the Court to find that there was a European consensus prohibiting disenfranchisement, and so it held that the State was granted a wide margin of appreciation. Notwithstanding this, the Court found that the UK had breached its obligations by adding a novel formulation to its determination of the margin of appreciation: that although it was very wide, it was not 'all embracing', and in the circumstances the UK's legislative measure constituted a breach of its obligations under the Convention. ${ }^{62}$

This approach was described in Judge Costa's dissent as 'depriving the state of all margin and all means of appreciation'. ${ }^{63}$ Yet it is not surprising that attempts to ground the margin of appreciation on the idea of European consensus led the Court into difficulties in this case. For although the UK's impugned practice of disenfranchising prisoners found support in the State practice of other members, this constituted a rare occasion in which the UK, a Western European State with a strong record for liberal democracy and human rights protection, found itself in a coalition of States with weaker reputations, including three of the four States responsible for more than half of the claims brought before the Court: Russia, Italy and Turkey. ${ }^{64}$

Thus the case represents an instance in which the two institutional commitments of the Court pulled in opposite directions, leading to a novel and controversial use of the margin of appreciation. The tension arises from the governance dilemma of seeking to secure universal human rights through transnational adjudication in the context of a system of voluntary participation of formally sovereign Member States. Seen this way, the difficulties in using State practice as a criterion for setting the margin of appreciation that can been seen in the Hirst judgment are obvi-

\footnotetext{
61 ibid, para 15.

62 ibid, para 82: 'Therefore, while the Court reiterates that the margin of appreciation is wide, it is not all-embracing'.

63 ibid, dissenting opinion of Judge Costa, para 9: 'The point is that one must avoid confusing the ideal to be attained and which I support - which is to make every effort to bring the isolation of convicted prisoners to an end, even when they have been convicted of the most serious crimes, and to prepare for their reintegration into society and citizenship - and the reality of Hirst (No 2), which on the one hand theoretically asserts a wide margin of appreciation for the States as to the conditions in which a subjective right (derived from judicial interpretation) may be exercised, but goes on to hold that there has been a violation of that right, thereby depriving the State of all margin and all means of appreciation'.

64 Bellamy provides some useful statistics highlighting the contrast between the UK and other members of this coalition (see Richard Bellamy, 'The Democratic Legitimacy of International Human Rights Conventions: Political Constitutionalism and the Hirst Case' in Follesdal, Schaffer and Ulfstein (n 51) 206. Since 1966, 97\% of the cases brought against the UK have been deemed inadmissible, with only $61 \%$ of those claims admitted held to have involved a breach of the Convention. By contrast, Russia, Ukraine, Turkey and Italy (who also imposed restrictions on the right of prisoners to vote) together account for more than half the cases brought before the Court, with Russia alone responsible for $27 \%$.
} 
ous consequences of the problems in balancing these two commitments. Like two oarsmen propelling the boat in opposite directions, the Hirst judgment shows us that any attempt to resolve this difficulty by setting the margin of appreciation on a principled basis is bound to lead the Court in circles, pushed at one moment this way, at another that, caught between the teleology of human rights theory, and respect for the sovereign autonomy and equality of its members.

One way, then, of characterising the governance effect of the margin of appreciation doctrine, and assessing the political stakes involved in the use of such a tool, might be to situate it in the context of this unarticulated preference for the practice of Member States from strong liberal democratic traditions. This might have implications for, and be informed by, theoretical debates about the universalist claims of human rights, and lead to a different assessment of whether they can be detached from social context, or whether they are firmly grounded in the particular visions of social order exemplified by the Western European states who drafted the Convention. ${ }^{65}$ It might then lead us to consider whether the Convention system, understood in such a way, embodies a 'centre-periphery' dynamic, akin to that which might be seen in the European Union, whereby the formal commitment to equality of the legal apparatus masks a deep-seated and differential treatment of Member States, broadly in accordance with the geographical fault-lines between Eastern and Western Europe. ${ }^{66}$ We might analyse the way in which flexible tools such as the margin of appreciation are deployed to mask potential clashes between the centre of the European human rights space, and those new members whose societies might embody very different visions of European liberal democracy (or those who might not be called liberal at all).

This section started with the critique that the European Court of Human Rights has discriminated against Member States by issuing harsher judgments against developing liberal democracies from the 'periphery'

\footnotetext{
65 Political theorist Charles Taylor argues that it is possible to detach human rights from their Western origin, by reinterpreting their claims at a higher level of generality, so as to make them compatible with non-Western forms of political communities: see Charles Taylor, 'Conditions of an Unforced Consensus on Human Rights' in The Belgrade Circle (ed), The Politics of Human Rights (The Belgrade Circle 1999) 101. Michael Freeden, 'European Liberalisms: An Essay in Comparative Political Thought' (2008) 7 European Journal of Political Theory 9, explores the connection between liberalism and human rights, and argues that liberalism encompasses a plurality of different modes that are found geographically dispersed across Europe. A deeper understanding of the relationship between human rights and liberal democracy might assist in identifying whether the judgments of the European Court are but one way among many of working out the implications of the abstract rights contained in the Convention, and whether that way is associated with particular, culturally specific visions of liberalism that dominated in the twentieth century.

66 Damjan Kukovec, 'A Critique of the Rhetoric of Common Interest in the EU Legal Discourse' (13 April 2012) <http://ssrn.com/abstract=2178332> accessed 30 May 2016.
} 
and those established States with high reputations for liberal democracy and human rights from the European centre. This observation was considered in the context of the 'consensus' standard for setting the margin of appreciation, and the difficult use of the margin in the Hirst judgment was suggested to be an expression of this tension between the commitment to formal equality of Member States, and the teleological understanding of human rights that sees the Convention system as a 'process' with a final destination. Finally, it was suggested that this provides a way of understanding the governance implications of the margin of appreciation, and that doing so might open up new ways of assessing the politics of the work of the European Court of Human Rights, which in turn might lead to a better clarification of the telos of an institution caught between the competing projects of an international legal order premised on the sovereign equality of States and the universalist claims of human rights.

\subsection{The margin of appreciation and the Court's strategy of judicial encroachment}

The purpose of this section is to situate the Court's flexible use of the margin of appreciation tool in the context of its challenge in ensuring compliance. ${ }^{67}$ This is a difficulty inherent in the institutional structure of the Court, as its foundation in a voluntary arrangement between governments deprives it of an effective enforcement mechanism. The Convention system's only institutional means of ensuring compliance with its judgments is the Committee of Ministers of the Council of Europe, which monitors the correction of violations by Member States. ${ }^{68}$ However, this procedure is less than effective, and the States responsible for the most findings of violations have a number of cases pending before the Committee. ${ }^{69}$ Despite this, many scholars regard the European Convention system as very effective at ensuring compliance, suggesting that in general States do comply with the Court's judgments. ${ }^{70}$

67 Dothan (n 58) 124-125 argues that this challenge in ensuring compliance can explain both its differential treatment towards some Member States (those that might be described as 'low reputation') and the phenomenon of it steadily issuing costlier and costlier judgments. This paper seeks to apply these insights to the specific example of the margin of appreciation, and hypothesises that its flexible nature means that it can be used as a tool to achieve both these ends.

68 See European Convention on Human Rights, art 46(2): 'The final judgment of the Court shall be transmitted to the Council of Ministers, which shall supervise its execution'. The Committee of Ministers has the power to expel a state from the Council of Europe as a sanction, but this threat has never been exercised, rending it of minimal value in generating compliance (Dothan (n 58) 119).

69 For example, the following States have had the highest number of cases pending for more than two years: Turkey (53), Italy (31), Bulgaria (28), Romania (23), Russia (22), and Poland (19). See Dothan (n 58) 120, fn 14 quoting from Council of Europe, Supervision and Execution of Judgments of the European Court of Human Rights, *66 Annual Report.

70 See Laurence R Helfer and Anne-Marie Slaughter, 'Toward a Theory of Effective Supra- 
The challenge in ensuring compliance is also increased by the trend, alleged by some commentators, of the Court issuing costlier and costlier judgments. ${ }^{71}$ This trend can result in a domestic backlash, even in those original Member States with strong traditions of human rights protection. ${ }^{72}$ Whilst this continued compliance poses a puzzle, one way of explaining States' willingness to comply with the Court's judgments despite the absence of an effective sanction mechanism is via the reputational cost that non-compliance might impose on the State. ${ }^{73}$ As such, States can be divided into 'high-reputation', those for whom noncompliance imposes a great cost on the Court's reputation, and 'low-reputation', those States for whom noncompliance is expected, and thus imposes little cost from the perspective of other States on the reputation of the Court. ${ }^{74}$ The suggestion, then, is that the Court, when issuing its judgments, must act strategically to 'walk on the brink of noncompliance' (ie increase the costliness of its judgments), by issuing the costliest judgments that it

national Adjudication' (1997) 107 Yale L J 273, 296: 'The rate of compliance by states with ECHR rulings is extremely high'.

71 See Erik Voeten, The Politics of International Judicial Appointments: Evidence from the European Court of Human Rights' (2007) 61 International Organization 669, 671, for the argument that aspiring EU members picked activist judges so as to bolster their State's human rights credentials as a precursor to accession.

72 For example, UK Supreme Court Justice Lord Sumption has repeatedly attacked the Court's evolutive interpretive methodology as an illegitimate expansion of the scope of the rights contained in the Convention text: 'It [the European Court] has over many years declared itself entitled to treat the Convention as what it calls a 'living instrument'... This approach has transformed the Convention from the safeguard against despotism which was intended by the draftsmen, into a template for many aspects of the domestic legal order. It has involved the recognition of a large number of new rights which are not expressly to be found in the language of the treaty'. See Lord Sumption, 'The Limits of Law: The $27^{\text {th }}$ Sultan Azlan Shah Lecture' (Kuala Lumpur, 20 November 2013) $7<$ http:/ / supremecourt.uk/ docs/speech-131120.pdf> accessed 30 May 2016.

73 Dothan (n 58) 119. However, the extent of this as an explanation, for compliance is limited by the observation that different governments, depending on the domestic political costs, might have strong motivations to strategically fail to comply with the Court's judgment. As such, the domestic political pay-off might outweigh the international reputational sanction arising from a failure to comply. This is easily seen in the UK context, where the failure to comply with the Hirst judgment since 2005 is used by the governing Conservative Party as a political badge of honour, and as part of a defence of British interests and sovereignty against the Convention system. Indeed, this is what led Prime Minister David Cameron to state in Parliament 'I see no reason why prisoners should have the vote. This is not a situation that I want this country to be in. It makes my physically ill even to contemplate having to give the vote to anyone who is in prison' despite the European Court already having ruled that automatic disenfranchisement was a breach of the UK's obligations under the European Convention (see HC Deb 3 Nov 2010, vol 517, col 921). Notwithstanding this, for the purposes of this paper it is enough to accept, all things being equal, that the Court might regard its own reputation as a factor in States' assessment of the costs of noncompliance.

74 Dothan (n 58) 120, fn 14: 'Low-reputation states are less expected to comply with the court; therefore states that have a lower rate of compliance with the court will be considered low reputation states'. 
believes will be complied with by high-reputation states. ${ }^{75}$ This powerful observation also helps explain the potential difference in treatment of Member States outlined in the previous section. For, if the reputational cost to the Court of non-compliance from a State with a weak tradition of respecting human rights is low, then the Court can be expected to issue costlier judgments against low-reputation states than high-reputation states, thus providing an alternative explanation for the apparent centreperiphery dynamic of the Court's adjudication. ${ }^{76}$

Seen in this context, another means the Court might employ to pursue a strategy of maximising compliance could be the development of flexible doctrinal tools that would assist it in 'walking on the brink of noncompliance'. Such tools would leave the Court the scope to decide cases in favour of the State, thus avoiding 'damaging confrontations' that might lead to noncompliance and a subsequent decrease in the Court's reputation. ${ }^{77}$ Thus we might regard the margin of appreciation as a governance tool that assists the Court in charting the difficult path between issuing costly judgments against respondent States, and the reputational harm it will suffer if strong liberal states do not comply. The flexible nature of the margin of appreciation, and the failure of the Court to develop clear, predictable and consistently applied justifications for its use, suggest that it is well suited to this task.

Such an observation may seem counterintuitive, as the ordinary understanding of the margin of appreciation is that it is a doctrine of deference that imposes limitations on the expansion of the Court's jurisdiction. Yet, as suggested above, it would be inaccurate to conceptualise the margin of appreciation as a per se limitation on jurisdiction. Indeed, rather than issue a statement of law holding that the substantive matter is outside the scope of the Court's jurisdiction as, say, a 'political question' doctrine, or a dismissal of an application as 'manifestly ill founded' might, even a determination that the State's margin of appreciation is

\footnotetext{
75 ibid 126, The Court will try to walk on the brink of noncompliance, issuing the most demanding judgments that it expects will lead to compliance, while still maintaining a small risk of noncompliance because of the inherent uncertainty of the state's costs. As the court's reputation grows, it can demand more in its judgments while still expecting compliance and maintaining only the small irreducible risk of noncompliance. In order to continue to walk on the brink of noncompliance, the court must increase the demands of its judgments as its reputation grows'.

${ }^{76}$ Of course, one can contest the assumption that the Court as an institution seeks to maximise the costliness of its judgments in the manner that critics suggest. Yet even if individual judges differ in their attitudes as to the proper scope of the Convention, or the balance between activism and restraint, the flexibility of human rights norms, and the way the margin of appreciation fails to prevent the capture of substantive issues as human rights issues suggests that there are institutional qualities that have facilitated the gradual expansion of the Court's jurisdiction, notwithstanding the possibility of opposition from individual judges.

77 Council of Europe (n 1).
} 
very wide recognises that the issue is one that engages Convention rights, thus leaving scope for the Court to apply the margin differently in future cases, or reduce it altogether in light of an evolutive interpretation of the Convention.

This understanding might lead to a new way of contextualising some of the Court's case law. For example, the Hirst judgment can be seen as an instance in which the Court was caught between the two elements of its institutional identity that pulled in opposite directions: its consensusbased jurisprudence, that led to the UK being granted a very wide margin of appreciation, set against the teleological assumptions of human rights that suggested that the practice of the low-reputation States with whom the UK formed a coalition ought to be disregarded. In this particular instance, the desire to secure a finding against the UK triumphed over the countervailing interest in legal certainty from consistency with its former decisions, and the search for a principled justification for the margin of appreciation based on European consensus. Principle gave way to flexibility in the judicial calculation (although the five-judge dissent suggests it was closely fought), but the UK's continuing non-compliance suggests that the Court might be expected to resolve such a conflict differently in future cases so as to avoid further loss to its reputation from the noncompliance of a high-reputation state like the UK. ${ }^{78}$

The explanation of the margin of appreciation found on the Council of Europe's website as giving the Court the 'flexibility needed to avoid damaging confrontations between the Court and the Member States' supports this conceptualisation of it as a legal-diplomatic tool, which is sometimes used for maximising compliance. As such, an analysis of its governance effects, seen in this light, would have to weigh the potential benefits of such a flexible tool in generating compliance against the costs that might ensue in legitimacy, via the unequal treatment of different Member States, depending on how the prospects of compliance are per-

78 This conceptualisation of the margin of appreciation as a 'legal-diplomatic tool', assisting the Court in its attempt to maximise compliance while issuing costlier judgments, seems plausible in light of the development of margin of appreciation jurisprudence. For example, in Handyside, the UK was granted a wide margin of appreciation in invoking the public morals exception that led to a finding of no breach. However, two years later in 1981, the Court found against the UK in Dudgeon, arguing that criminalisation of certain homosexual acts was contrary to a developing European consensus, and thus warranted a narrow margin of appreciation, despite the State relying on the same 'public morals' justification, and the existence of a European consensus being strongly denied in a dissenting judgment by Judge Zekia (six judges dissented in total): see Dudgeon $v$ United Kingdom (1981) 4 EHRR 149. One can hypothesise that the margin of appreciation might have been developed in the early days as a tool to generate compliance respect, which is cashed in at crucial moments when the Court thinks the stakes are sufficiently high (such as decriminalisation of homosexuality) yet not in other cases (such as Handyside, concerning restrictions on the publication of a book) where the substantive issue does not warrant the risk of possible noncompliance. 
ceived by the Court. ${ }^{79}$ This in turn might lead to a new understanding of what the margin of appreciation tells us about the balance of power between the two conflicting aspects of the Court's identity, accompanied by a subtle shift in rhetoric. For rather than the margin of appreciation being the space that the Court grants to the Member States, instead we might regard it as something more nuanced: a prima facie acceptance by the Court of the limitations on its governance power inherent in its structure, yet at the same time a flexible tool that provides the means to decrease, if not permanently transcend, those limitations. Whether or not there are other doctrinal moves that can resolve this tension without the cost that flexibility imposes on legitimacy, and how we might begin to think about those in political terms, will be considered in the final section.

\section{Judicial rulership and the politics of separation of powers}

The purpose of this final section is to draw together the interpretations of the governance effects of the margin of appreciation offered in sketch form above, by attempting to situate the European Court of Human Rights as an institution of global governance closely associated with a particular period of legal thought, involving widespread judicialisation of constitutional and human rights norms. ${ }^{80}$ The aim is to consider what impact this contextualisation of the Court has on these interpretations of the margin of appreciation, and whether an enhanced consciousness of this context might open up new possibilities for the Court's jurisprudence, which might in turn have an impact on the exercise of its governance power. ${ }^{81}$ It is suggested that the use of the margin of appreciation as an 'escape valve' to avoid relying on the Court's own proportionality assessments involves a kind of Sartrean 'bad faith', as doing so disguises an implicit ranking of interests, yet has an equivalent governance effect. An enhanced consciousness of this understanding of the margin's

\footnotetext{
79 This picture might also lead us to new ways of analysing the work of particular judges on the Court, for example as the distinction between 'activist' and 'conservative' judges would be complicated by the fact that the margin can be wielded as a short-term strategic tool for generating compliance respect by granting the state a wide margin of appreciation.

80 This section follows Duncan Kennedy's tripartite periodisation of legal thought into 'Classical Legal Thought', 'Social Legal Thought' and 'Contemporary Legal Thought', each of which is characterised by different dominant methodologies, legal philosophies and governance ideas. See Duncan Kennedy, 'Two Globalizations of Law \& Legal Thought: 1850-1968' (2002) 36 Suffolk University Law Review 631, 632.

81 The idea that an enhanced consciousness of governance power might lead to more responsible exercises of that power follows David Kennedy's suggestion. In several papers, he calls for an 'enhanced consciousness of rulership' among human rights activists, arguing that 'ambivalent rulership is often rulership denied' (see David Kennedy, 'The International Human Rights Regime: Still Part of the Problem?' in Dickinson and others (n 17) 23), and among experts participating in global governance, yet in a state of denial about their governance power (see Kennedy (n 45)). This section seeks to apply this insight to judges in the European Court of Human Rights.
} 
governance implications might lead the Court to place greater emphasis on its own proportionality and balancing analyses, which in turn would require a renewed focus on the 'politics of the separation of powers', and the Court's legitimacy.

\subsection{The European Court of Human Rights in contemporary legal thought}

Kennedy offers a tripartite periodisation of law and legal thought, tracing its development from 'Classical Legal Thought', through 'Social Legal Thought', to 'Contemporary Legal Thought', the current paradigm. None of these paradigms is supposed to be exclusionary, in the sense that each represents a body of techniques that can emerge to a greater or lesser extent in each period. The purpose of the periodisation is simply to identify certain legal tropes that have dominated in particular periods, as part of a complex process of reaction and counter-reaction. As such, 'Contemporary Legal Thought' is characterised by the following key features: a legal core centred on constitutional law, 'rights and policies' as a dominant normative idea, conventions and constitutions as key legal instruments, the balancing of conflicting interests as a dominant mode of analysis, and the relationship between law and politics as a fundamental problem. ${ }^{82}$

Another way of characterising the features of this paradigm might be as involving 'the adaption of law to the rationality of politics' ${ }^{83}$ As such, law, both in terms of its methodology and promise, could be understood as political in the Weberian sense: a domain in which different values clash, with no way of maximising them all simultaneously, and the role of politics (now law) is to choose between which to prioritise in a given context, at the expense of which others. ${ }^{84}$ That law might incorporate this rationality can be explained as the consequence of the juridification of social life through the growth of the administrative state, the judicialisation of that juridified regime, and the subsequent shift of power to constitutional law (and thus constitutional lawyers and judges) that accompanies constitutionalisation. ${ }^{85}$

\footnotetext{
82 Kennedy (n 80) 632.

83 See Teubner (n 49) 21: ‘...constitutional law has liberated the intrinsic logic of politics by "politicising" the law itself: teleological interpretation, policy orientation, balancing of interests, impact assessment and result-orientation are indicators of an adaptation of law to the rationality of politics'.

84 See Max Weber, 'Politics as a Vocation' in P Lassman and R Spears (eds), Weber: Political Writings (CUP 2003).

85 See Duncan Kennedy, 'Three Globalizations of Law and Legal Thought: 1850-2000' in David M Trubek and Alvaro Santos (eds), The New Law And Economic Development: A Critical Appraisal (CUP 2006)
} 
A key feature of Contemporary Legal Thought, then, involves the explicit application of proportionality and balancing analyses to provide the final resolution of legal problems. For Kennedy, these techniques emerge as a 'last resort', when the legal materials fail to point to a particular solution that can be presented as legally necessary. However, the characterisation of proportionality and balancing analyses as last resorts seems at odds with the practice of the European Court of Human Rights, and suggests it might present a special case. This is because, for a Court in which the basic legal materials are a Convention text that contains a schedule of rights, with no clear hierarchy, it is unsurprising that the clash of those rights and interests that can be seen in every case would be resolved through explicit applications of proportionality and balancing of interests. The success and expansion of the European Court of Human Rights, then, might be seen as the apotheosis of this process, facilitated by the flexible qualities of human rights that make them apt tools for constitutionalisation, even in States traditionally hostile to constitutional review via human rights. ${ }^{86}$

As such, seen in this context, the European Court of Human Rights takes on a new aspect: as the institutional embodiment of Contemporary Legal Thought, and its embracing of the collapse between law and politics as separate domains, accompanied by the growing dependence on proportionality and balancing of interests as methods of resolving the cases before it. This fusion of law and politics in a heuristic that offers the potential resolution of any political problem is in keeping with both critiques of human rights that historicise human rights as the current dominating universalist ideology, and the triumphalism that can be seen sometimes in the Court's self-image, for example in descriptions of the Court as the 'crowning achievement... perhaps in the history of all law'. ${ }^{87}$

\footnotetext{
86 Tom Hickman, Public Law After the Human Rights Act (Hart 2010) 1 provides an overview of the way in which human rights principles have 'transformed public law in the United Kingdom', both before and after the formal incorporation of the European Convention into domestic law in 1998. Hickman describes the effect of human rights as in the UK as involving the 'reconfiguration of public law so that modern civil and political rights and freedoms, as set out in post-war international human rights instruments, are at its core and radiate even into areas seemingly distant from human rights concerns, such as planning disputes, taxation and hunting with hounds, to name but a very few'.

87 See, for example, Samuel Moyn, The Last Utopia (HUP 2010), for a historical critique of the teleological tendency of human rights theorists and supporters to trace their origins to the beginning of time, instead suggesting that human rights as the dominant universalist project of today only achieved its current form in the 1970s, facilitated by the collapse of other ideological universalist projects. That the Court itself embraces the utopianism of human rights can be seen from statements such as the following, by Michael O'Boyle, the Court's Deputy Registrar, describing the Court as 'one of the major developments in European legal history and the crowning achievement of the Council of Europe. The emergence of the authority of the European Court of Human Rights has been described as one of the most remarkable phenomena in the history of international law, perhaps in the history of all law' (see Anthony Lester, 'The European Court of Human Rights after Fifty Years' in Christoffersen and Madsen (n 56) 98.
} 
But if we accept this contextualisation of the European Court as the institutional apotheosis of contemporary legal thought in a transnational context, what bearing does this have on our understanding of the margin of appreciation? What impact might a greater understanding of this have on its judges, and their approach to this tool?

\subsection{Judicial rulership and the margin of appreciation}

One possibility is that a greater consciousness of the methodology of Contemporary Legal Thought might have an emancipatory effect, lessening the Court's dependence on the margin. The relationship between the margin of appreciation, proportionality and balancing is complex. ${ }^{88}$ Notwithstanding this, the Court has attracted criticism from practitioners for using the margin of appreciation as a tool to avoid having to undertake its own detailed proportionality and balancing assessments. ${ }^{89}$ As such, this institutional context makes the development of a tool such as the margin all the more curious, and seemingly at odds with the zeitgeist of Contemporary Legal Thought, as expressed in the European Court via the utopianism of transnational human rights.

For if the dominant characteristic of legal reasoning in this period, in keeping with the 'adaptation of law to the rationality of politics', is the emphasis on conflicting considerations, and a style of reasoning that resolves legal questions through proportionality and balancing analyses, then that these legal techniques should emerge as a key feature of the jurisprudence of the European Court of Human Rights is unsurprising. Contra domestic courts, its dependence on a human rights treaty suggests that the solutions to all its legal questions will be expressed explic-

\footnotetext{
88 For example, Legg (n 12) 177 argues that proportionality analysis and the margin of appreciation are mutually constitutive of a comprehensive theory of human rights adjudication. Others argue that proportionality and balancing pose a threat to the very concept of human rights: see, for example, Stavros Tsakyrakis, 'Proportionality: An Assault on Human Rights?' (2009) 7 International Journal of Constitutional Law 468. For the purposes of this paper, it is not necessary to engage in great detail with these complex theoretical questions about the relationship between these concepts. However, it is suggested that it is unhelpful to posit a necessary connection between the margin of appreciation and proportionality analysis, and in fact the historical origins of both suggest that they ought to be seen as contingent doctrinal choices that push in different directions. This is evident when one considers the historical genealogy of proportionality, which suggests its emergence posed a challenge to the doctrinal precursors of the margin of appreciation, by providing a rational basis for the expansion of judicial power. See Alec Stone Sweet and Jud Matthews, 'Proportionality Balancing and Global Constitutionalism' (2008) 47 Columbia Journal of Transnational Law 72, 78: 'In most Continental systems, like France and Italy, courts used, pre-proportionality, various standards, including "manifest error of appreciation" (granting very wide deference)...'

89 See Lester (n 87) 102: 'The problem with the Court's loose invocation of the margin of appreciation is that it removes the need for the Court to discern and explain the criteria appropriate to particular problems. What is needed is a careful, skillful, and consistent application of the principle of proportionality'.
} 
itly in terms of proportionality and balancing. ${ }^{90}$ The majority, if not all, of its cases can only be resolved by the Court deciding that one particular right, or interest qua permitted exception to a right, was more important in a given context. This moment of decision, which is rationalised through proportionality and balancing analyses, is thus a fundamental and inescapable aspect of a Court premised on human rights derived from a treaty-based text..$^{91}$

As such, the Court's preference for resolving disputes by using the margin of appreciation to defer to the Member States' own proportionality assessments, suggests a 'flight from rulership', and an unwillingness to embrace this fundamental aspect of the Court's governance function. The margin, then, might be characterised as an 'escape valve' that the Court uses to avoid it having to take a stand in substantive issues of policy, and grasp the difficult task of deciding, where the legal materials necessarily cannot point to a particular conclusion.

Of course, it might be argued that the development of a tool to avoid particularly 'damaging confrontations' with the Member States is necessary, given the treaty-based origins of the system. Yet even if this were justified as a means of retaining the States' consent to participate in the system, then, it is suggested, this would still involve a kind of Sartrean 'bad faith'. ${ }^{92}$ For not only would the judgments fail to reflect the real reasons for the margin of appreciation being applied, but its use would still involve the very ranking of interests that the Court might seek to avoid through using it. The decision that a particular case is sufficiently controversial to justify the use of the margin itself involves an implicit ranking

\footnotetext{
90 Some legal sceptics might suggest that all judicial decisions, in whatever field, ultimately reduce to the application of principles similar to proportionality and balancing. Whether or not this is the case, the European Court of Human Rights is surely unique in its dependence on these techniques as the dominant and explicit ways of rationalising its decisionmaking process.

91 Stone Sweet and Matthews (n 88) 78 argue that proportionality emerged precisely as a means of protecting judicial decisions over constitutional matters from attacks on legitimacy. As a legal technique, then, it offers a way of rationalising a given policy decision in a judicial context: '[proportionality analysis] does not camouflage judicial lawmaking. Properly employed, it requires courts to acknowledge and defend - honestly and openly - the policy choices they make when they make constitutional choices.... not a magic wand that judges wave to make all of the political dilemmas of rights review disappear. Indeed, waving it will expose rights adjudication for what it is: constitutionally-based lawmaking'.

92 'Bad faith' is taken to mean a self-deception about the necessity of acting in a certain way, and as such implies a denial of freedom, and the responsibility inherent in making a particular choice, referred to above as a 'flight from rulership'. See Jean-Paul Sartre, Being and Nothingness (first published 1943, Citadel Press 2001) 448: 'It should be observed first of all that the choice of total ends although totally free is not necessarily nor even frequently made in joy. We must not confuse our necessity of choosing with the will to power. The choice can be effected in resignation or uneasiness; it can be a flight; it can be realized in bad faith. We can choose ourselves as fleeing, as inapprehensible, as indecisive, etc. We can even choose not to choose ourselves...' (emphasis added).
} 
of interests, as does the decision to accept the State's arguments that some issues fall under the 'public morals' exception, and others do not.

At the same time, granting the State a wide margin of appreciation still entails the significant exercise of governance power: for it resolves the issue decisively in favour of one party, and has the same legal effect in the respondent State, and throughout the Convention system, via the Court's jurisprudence. To deny this aspect of the Court's rulership is to ignore the governance power it wields when it uses the margin of appreciation, and suggests a flight from its governance function, perhaps motivated by a fear about its competence or ability to generate compliance, were it to embrace more wholeheartedly the proportionality and balancing characteristics of contemporary legal thought, of which it is the ultimate expression.

\subsection{The politics of separation of powers in a transnational context}

What might a greater acceptance of this aspect of the Court's governance power entail? If its judges were to embrace the possibilities of this form of rulership, how might this affect our analysis of the Court, and its role in global governance? Of course, the natural and longstanding objections to these processes of judicialisation and constitutionalisation take the form of institutional competence and legitimacy arguments, which contend that courts are inappropriate institutions for the exercise of this governance function. Indeed, such objections have spawned an entire discourse in the particular context of the European Court, as theorists search for different ways to legitimate the project of transnational adjudication of human rights. ${ }^{93}$ Yet the analysis of the political stakes inherent in the Court's use of the margin of appreciation doctrine outlined in this paper suggest that its continued use might also pose challenges to the Court's legitimacy. Its flexible use, and the way it gives the illusion of the Court avoiding taking a stand on the underlying substantive issue, whilst deciding the case in favour of the State, alongside the differential treatment of Member States, suggests that the margin of appreciation itself might pose significant challenges to the long-term legitimacy of the Court that ought to play a part in our assessment. ${ }^{94}$

\footnotetext{
93 See Follesdal and others (n 51) for a variety of approaches to considering legitimacy in this context.

94 Indeed, there is no suggestion that the consent of the Member States at present poses a threat to the system, despite the fact that the Court has issued increasingly costly judgments against Member States in a process of continual expansion. Through the Protocols, the States have added new rights, expanding the Court's governance capacity. Moreover, at the 2012 Brighton Conference, the suggestion that art 35 ought to be amended to include the margin of appreciation was rejected (instead, a reference to the margin of appreciation will now appear in the Preamble). See Spielmann (n 50) 383.
} 
One might then seek to respond to these institutional competence arguments with novel justifications that situate the Court as an institution of global governance, perhaps through the argument that separation of powers in a transnational context requires not necessarily the differentiation of governance functions per se, but rather institutional differentiation over the same governance functions. ${ }^{95}$ A greater understanding of these sets of arguments might free the Court from concerns about settling issues decisively using its own balancing and proportionality analyses, as, rather than intruding on the rightful function of domestic governance institutions, the Court would instead be participating in a process of mutual interaction, whereby the fallibility of either institution to ensure the effective protection of human rights is checked by the participation of the Court in the same process.

Yet while this might provide judges and scholars with the argumentative tools to lessen dependence on the margin of appreciation, a deep analysis of the stakes involved in such an empowered court would be required - a 'politics of the separation of powers', understood in the context of transnational adjudication. ${ }^{96}$ This new type of analysis would have to be capable of identifying the stakes involved in a more forthright exercise of this governance function by the European Court. It would not be sufficient merely to identify those stakes as a shifting of power away from domestic institutions towards the Court itself. Rather, there would need to be some way to conceptualise those stakes in substantive (not merely constitutional) political terms. Which groups would be advantaged or disadvantaged by such an empowered Court? Would some individuals or organisations be better able to mobilise this architecture than others? Does this model of developing constitutional norms tend to advantage particular sides in certain political conflicts more than others? What are the political stakes in this form of constitutionalisation?

Whilst this paper cannot provide full answers to these difficult questions, the possible interpretations of the governance effects of the margin of appreciation offered in sketch form above can suggest some ways of thinking about them. We might, for example, embrace an understanding of human rights per se as an 'ideology' that allows us to critique its limitations as a mode of resolving disputes, not from within human rights itself, but by elaborating the boundaries of the discourse. That might, say, lead to an understanding of the limitations involved in a technique of conflict resolution that is tightly linked to the political theory of liberal-

\footnotetext{
95 Indeed, this is what is often referred to both in the Strasbourg jurisprudence and the scholarship as the 'dialogue' between the Court and domestic institutions. See Slaughter (n 48).

96 See Duncan Kennedy, 'The Hermeneutics of Suspicion in Contemporary American Legal Thought' (2014) 25 Law and Critique 91.
} 
ism, in its Western European form. We might, in the particular context of the European Court of Human Rights, assess the impact on different political conflicts of the capture of transnational processes of constitutionalisation by an institution that requires an individual to have suffered harm in a particular national context, and then resolves that issue by generating constitutional norms that have their purchase within that national context, before diffusing throughout the Convention system as a whole. Such an analysis might lead us to consider whether the capture of this process by an institution sitting at the apex of the traditional nationstate hierarchy of legislature, constitutional court, then international human rights court, solves the problems of the nation-state, or whether it actually enhances its limitations, pushing against the twenty-first century sociological context of disaggregation of regulatory functions among a variety of transnational public and private actors.

The politics of the separation of powers in this particular institutional context might also require us to take seriously critiques of the Court's difference in treatment of Member States. This might lead us to conceptualise the stakes in these circumstances as those suggested by the earliest critiques of the margin of appreciation - the tension between universality and pluralism, except that, rather than occurring at the abstract level of human rights theory, this conflict could be given a practical expression through an analysis of differential treatment, and the subsequent costs to legitimacy this might impose. We could then set this in the wider context of European integration, and assess the impact of the Court on this process, and whether the rhetoric of human rights might be shorthand for a new form of civilising mission, disguising a relationship of tutelage between the European centre and periphery. Finally, taken as a whole, the phenomenon of the Court's steady encroachment on States must itself have political stakes, in that its success or failure must have some purchase on the outcome of the conflicts that it is called upon to resolve. If law has adapted to the rationality of politics in the institutional setting of the European Court, and the Court were to embrace the techniques of that rationality via proportionality and balancing of interests, then this might require an intensity of focus on the composition of the bench, and the importation of tools developed in critical legal studies, starting from the assumption that if in such an institution law and politics are fused, then we ought to enhance our knowledge of who our rulers are, to better elucidate the politics of the separation of powers.

In summary, the Court's development of the margin appreciation as a tool is linked to its unwillingness to resolve decisively issues of political controversy using the contemporary legal thought methodologies of interest balancing and proportionality. Yet those techniques are not merely expressions of the current paradigm of constitutionalisation (that alone 
would not be an argument for their use), but are also closely connected to the Court's identity as an institution exercising governance power through human rights adjudication. This institutional identity provides not only the possibility of substantive solutions to political conflicts, but also the method of their resolution, through the tools of proportionality and balancing of interests. That the Court has developed the capacity to resolve cases without relying on its own application of these tools suggests a denial of its governance power, and the victory of one of our two oarsmen in the struggle for the Court's identity, even as its power extends progressively further. This is not to suggest that judges ought to embrace wholeheartedly that expansion of the Court's reach - only that a greater consciousness of the political stakes inherent in this kind of rulership might lead to a more responsible exercise of that power, including when it takes the form of the margin of appreciation.

\section{Conclusion}

This paper has argued that the margin of appreciation can be seen as the expression of a governance dilemma, arising from the challenge of judicialising the protection of human rights in a transnational context. The nature of the challenge involves a clash between the competing claims of two twentieth-century projects of global governance: the sovereign equality of nation-states as the foundation of international law, and the universalist claims of human rights. The presentation of the margin of appreciation by the Council of Europe as an 'inherent and permanent phenomenon', and the search for principles on which to base its use, must be seen in this light. The purpose of this paper has been to challenge the rhetoric of necessity surrounding the margin of appreciation, and instead to recapture its contingency as a solution to this governance dilemma, by suggesting ways of thinking about its governance effects, and the political stakes that arise from the use of such a tool.

The first part of this paper provided a brief overview of the current state of scholarship regarding the margin of appreciation. It was argued that the tendencies of the literature to either analyse the margin of appreciation as a judicial doctrine or as an abstract threat to the universalism of human rights both failed to capture the flexible nature and governance implications of its use. An analysis of some of the common problems with justifications for deploying the margin of appreciation led to the suggestion that it be reconceptualised as a 'governance tool'. The remaining sections sought to analyse the margin in this light, providing four sketches of its possible governance effects.

The first such sketch placed the European Court of Human Rights in the context of broader processes of transnational constitutionalisation, 
and argued that the margin of appreciation takes a stake in the conflict between nation-state centric and disaggregated visions of constitutionalisation, by capturing substantive issues as human rights issues, and reverting constitutionalising capacity back to the public institutions of the Member States. The second sketch suggested that another way of understanding the Court's use of the margin of appreciation as a governance tool is as an aspect of the unarticulated discrimination between Member States. This discrimination, it was suggested, arose from the tension between the universalism of human rights, which suggested a preference for the practice of certain Member States, and the formal commitment to the sovereign equality of states arising from its treaty-based foundation. It was argued that this formal equality had little bearing on its practice, as could be seen from the Court's inconsistent use of the consensus justification for the margin of appreciation.

The third sketch then sought to situate the margin of appreciation in the context of the Court's challenge in ensuring compliance with its judgments. It was suggested that the flexibility of the margin of appreciation facilitates its use as a tool to aid in the Court's strategy of jurisdictional encroachment, by issuing costlier judgments against low-reputation States than high-reputation States, or using the margin in an ad hoc way to avoid suffering a reputational hit by issuing a costly judgment unlikely to be complied with. The final section sought to bring these other claims together, by offering an understanding of the margin of appreciation as a 'flight from rulership', and an attempted abnegation of the Court's governance power in failing to resolve certain cases using its own proportionality assessments. It was suggested that this was a kind of 'bad faith', as the use of the margin of appreciation still required the Court to take a stake in substantive issues of interest balancing, and still involved an exercise of its governance power due to the significant legal effect in Member States. Finally, it was argued that a greater consciousness of this might liberate the Court to embrace the possibilities of its rulership and exercise its governance power more responsibly - but that this in turn would lead to a renewed focus on the 'politics of the separation of powers' in a transnational setting.

Whatever the governance effects of this judicial tool, its recent inclusion in the Preamble of the Convention suggests that it is likely to remain a part of the Court's jurisprudence for the foreseeable future. This paper has not sought to express a view on whether this consolidation of the margin of appreciation per se is desirable, but it has attempted to remove the aura of necessity surrounding it. The complicated politics of the margin of appreciation are closely connected to the institutional identity of the European Court, an identity with conflicting strands. Whether or not we celebrate or bemoan its continued existence ought to depend on 
a proper assessment of its politics, however difficult such an assessment may be. It is hoped that these four sketches of ways of thinking about the governance effects of the margin of appreciation might contribute to this - and in so doing help distinguish between what is contingent and what is necessary in the European Court of Human Rights and the exercise of its governance power in the European constitutional space. 